Artikel Konseptual

\title{
PENDIDIKAN KARAKTER MELALUI MEMBACA KISAH TOKOH SEJARAH: MENELUSURI PIJAKANNYA
}

\author{
Susanto Yunus Alfian \\ susantoyunusalfian@gmail.com \\ Guru Sejarah di SMAN 1 Sumberpucung, Kab. Malang \\ Abstract. In the implementation of the curriculum 2013 the Government focus on the \\ strengthening of character education especially five characters namely religious, nation- \\ alist, mutual, integrity and independent. The characters can be imitated from historical \\ figures. In order to fulfill this goal, history teacher can use serial books historical figures \\ for learning characters. The use of stories can be an effective way to teach the virtues of \\ character. Why the story of the historical figures can be used to teach character to stu- \\ dents? to answer it, this paper reveals the contributions of cognitive schema, initial \\ knowledge, and the construction of meaning in the process of reading the stories of his- \\ torical figures.
}

Key words: character education, stories, historical figures, cognitive scheme, initial knowledge, mental representation

\section{PENDAHULUAN}

Pemerintah menekankan penguatan pendidikan karakter dalam Kurikulum 2013. Penguatan pendidikan karakter yang selanjutnya disebut PPK dilaksanakan dengan menerapkan nilai-nilai Pancasila dalam pendidikan karakter terutama meliputi nilai-nilai religius, jujur, toleran, disiplin, bekerja keras, kreatit mandiri, demokratis, rasa ingin tahu, semangat kebangsaan, cinta tanah air, menghargai prestasi, komunikatif, cinta damai, gemar membaca, peduli lingkungan, peduli sosial, dan bertanggungiawab (Perpres No. 87 tahun 2017). Tentu saja pelaksanaan pengajarannya berimplikasi pada tugas guru sehari-hari termasuk guru matapelajaran Sejarah Indonesia. Oleh karena itu disamping mengajarkan isi pelajaran sejarah, guru juga mengajar siswa untuk berbuat baik atau berkarakter baik (Narvaez, 2001). Contoh-contoh perbuatan baik tersebut dapat ditemukan dalam kisah tokoh-tokoh sejarah.

Buku-buku serial tokoh sejarah yang beredar di pasaran bisa dimanfaatkan untuk pembelajaran karakter. Penggunaan cerita-cerita atau kisah-kisah bisa menjadi cara effektif untuk mengajarkan karakter kebajikan (Sanchez et al., 2009; Vitz, 1990; Walker \& Lombrozo, 2017). Kisah-kisah di kitab suci bisa dijadikan sebagai bahan untuk mengajarkan pelaku-pelaku kebajikan. Kisah-kisah itu bisa menginspirasi anak-anak. Mereka bisa 
melakukan tindakan kebajikan yang berasal dari pengalaman mereka yaitu dari cerita yang diterimanya. Subur (2015) telah memelopori bagaimana mengajarkan karakter melalui kisah-kisah keagamaan tersebut dsi Indonesia. Suatu program pendidikan karakter yang bernama Heartwood Institute's "An Ethics Curriculum for Children" merupakan suatu contoh program yang menekankan pada cerita (Prestwich, 2004). Cerita-ceritanya berisi nilai-nilai etika yang diajarkan ke siswa. Siswa diajak mendiskusikannya, dan terakhir siswa diajak untuk melakukannya.

Seiring dengan program literasi yang digelorakan secara nasional yang bisa dijadikan sebagai pengajaran langsung karakter, bacaan-bacaan yang mengisahkan contoh kebajikan bisa menjadi salah satu solusi. Tentu saja sebagai guru matapelajaran Sejarah Indonesia, kisah para tokoh sejarah Indonesia bisa dimanfaatkan untuk pembelajaran karakter melalui kisah mereka, misalnya saja buku yang berjudul "S.K. Trimurti: Pejuang Perempuan Indonesia" karya Ipong Jazimah (2016). Dalam tulisan ini, penulis tidak memaparkan bagaimana pendidikan karakter melalui kisah, tetapi penulis berusaha untuk berbagi pendapat tentang alasan keefektifannya. Untuk itu struktur tulisan ini dimulai dari pengaruh membaca kisah, peranan pengetahuan awal dan sekema kognitif, dan hasil membaca yang berupa representasi mental.

\section{PENGARUH MEMBACA KISAH PADA MORAL SISWA}

Pengembangan keputusan moral dari membaca telah banyak diteliti pengaruhnya. Partisipan diberi bacaan-bacaan tentang dilema moral. Dari membaca dilema-dilema moral, siswa bisa mengingat kembali tentang bacaan yang telah dibacanya. Contohnya adalah ibu miskin yang harus membayar pengobatan dirinya. Dalam bacaan tersebut, disajikan alasan-alasan atau argumen-argumen berbagai tingkatan keputusan moral. Argumen moralnya disajikan dengan lengkap dan mendalam. Di situ disajikan rasionalisasi dan interpretasi tentang peristiwa-peristiwa dilema moral yang ada. Partisipan diminta hanya me-recall tindakan-tindakan yang ada pada bacaan itu dan juga alasan atau pemikiran-pemikiran di balik keputusan yang diambil. Partisipan harus memikirkan tentang keputusan yaitu tentang alasannya dan juga merekonstruksi apa yang terjadi.

Beberapa penelitian menunjukkan bahwa perlakuan membaca memberi pengaruh positif pada karakter siswa (Almerico, 2014). Setelah membaca teks tentang moral, siswa diminta untuk mengingat kembali apa yang telah dibacanya. Siswa yang mendapat skor lebih tinggi diharapkan dapat merekonstruksi argumen lebih banyak saat mereka me-recall. Siswa yang kemampuan nalarnya tinggi juga bisa menalar lebih tinggi pada kegiatan me-recall (Bower, G. H. 1976). Penelitian lain lagi juga menunjukkan pengaruh membaca 
(Gambrell \& Jawitz, 1993). Hasil penelitian menunjukkan bahwa membaca teks moral berpengaruh pada peningkatan keterampilan pemahaman. Perkembangan moral pembaca atau pengetahuan awalnya tentang moral berpengaruh juga terhadap recallnya tentang teks moral yang rumit. Teks moral yang digunakan dalam pendidikan karakter sebaiknya berisi cerita-cerita moral yang sederhana.

Penganut pendidikan karakter tradisional menganjurkan pendidikan dengan cara modeling dan cara pengajaran moral langsung. Akan tetapi mereka masih belum memiliki resep bagaimana mengajarkannya. Mereka membuat cerita-cerita moral dan menyerahkan begitu saja kepada guru untuk mengajarkannya. Hal seperti itu disebut moral contagion (penularan kebaikan). Dan asumsinya adalah bahwa dengan membaca sendiri mereka akan dapat menangkap isinya dengan sendirinya.

Anak-anak menangkap dan menyaring pesan moral tidak bisa lepas dari konteks lingkungan sosialnya. Ada interaksi antara mereka dan lingkungannya (Terwel, 1999). Tema moral dan kebajikan tidak bisa dikomunikasikan hanya dengan membaca saja. Dari beberapa penelitian menunjukkan bahwa anak tidak bisa menangkap pesan yang ingin disampaikan oleh penulisnya. Ada konteks sosial yang berinteraksi dengan mereka. Pengaruh lingkungan sosial itu bisa mempengaruhi pemahamannya terhadap pesan moral yang ada dalam bacaan.

Paham tradisional beranggapan bahwa dengan membaca cerita moral anak bisa mengembangkan karakternya. Dibandingkan anak-anak, tentu orang dewasa jauh lebih ahli dalam berbagai kegiatan. Lemahnya pada orang dewasa terletak pada daya ingatnya. Itu bukan menjadi soal. Yang perlu ditekankan adalah pada pemanfaatan cerita moral bagi pendidikan karakter siswa.

Pembelajaran karakter di sekolah yang dilakukan dengan cara membaca cerita karakter sangat berdampak positif (Agboola \& Tsai, 2012; Lee et al, 2014; Almerico, 2014). Membaca kisah karakter yang dapat dikategorikan sebagai pengajaran langsung bisa menjadi efektif dalam pembelajaran karakter (Tyra, 2018).

\section{PENGETAHUAN AWAL}

Dalam membaca teks, orang yang membaca sebenarnya merupakan active comprehenders (orang yang memahami bacaan secara aktif). Orang yang membaca selalu menggunakan pengetahuan awalnya dan juga mengkonstruksi makna dari teks yang dibaca tersebut. Dengan kata lain, ketika seorang membaca dan mengingat teks, dia akan memahaminya dengan jalan mengintegrasikan informasi di teks dengan pengetahuan 
awalnya. Pengetahuan awal tersebut berpengaruh kepada memori terhadap teks yang dibaca (Recht et al, 1998).

Pembaca pasti secara aktif mencari makna dan mengkonstruksi interpretasinya dengan didasarkan pada pengetahuan awalnya. Setiap pembaca mengkonstruksi suatu representasi dari suatu teks yang dibacanya. Jika teksnya berupa topik yang sudah dikenalnya, maka pembaca akan lebih mudah memahaminya. Sebaliknya jika teksnya tidak memiliki kaitan dengan pengetahauan awalnya atau dengan skema yang dia miliki, dia akan lebih banyak mengalami kesulitan untuk memahaminya. Pengetahuan awal sangat menentukan dalam pemahaman bacaan (Liu et al, 2014).

Pembaca bukanlah passive assimilators (orang yang memahami secara pasif). Sebaliknya, mereka justru secara aktif mengkonstruksi makna dari teks dengan menggunakan pengetahuan awalnya. Sebagai akibatnya, pembaca tidak menerima saja the same mental representation (menyalin apa adanya) dari teks. Dengan kata lain pembaca secara aktif menghonstruksi makna dengan dasar pengetahuan awalnya.

Segala sesuatu yang diterima atau dipersepsi ditafsirkan dengan menggunakan pengetahuan awal (Kelly, 2014; Caillies, 2002; Recht, 1988) dan skema yang telah ada di otak (Derry, 1996; Smith \& Swinney, 1992; Narvaez, 1998). Koherensi teks sangat mempermudah dalam membangun makna, apalagi ditambah pengetahuan awal yang kuat (Kamalski et al, 2008). Bila koherensinya rendah, isi teks tersebut mudah sekali terlupakan atau sulit diproses (Bower, 1976).

\section{SKEMA KOGNITIF}

Menurut para ahli, skema kognitif (struktur pengetahuan pembaca) yang relevan dengan bacaan bisa membantu pembaca dalam mengkonstruksi representasi mental terhadap teks yang dibacanya (Driver et al, 1994). Dalam memahami wacana, sebenarnya pembaca membuat kesimpulan yang asalnya dari pengetahuan yang telah dimilikinya. Di situ akan terbangun skema (Zhang, 2010). Skema tersebut dibawa ke otak atau diaktifasi oleh konfigurasi stimuli yang menggambarkan stimuli yang lalu atau pengalaman pribadi. Pembaca membangun mental model dari teks yang dia baca dan juga menarik kesimpulan yang didasarkan pada model tersebut. Skema cerita dalam teks menentukan skema yang dibangun oleh pembacanya (Stein \& Trabasso, 1981).

Menurut pandangan konstruktivisme yang dibangun dari padangan Ausubel, Piaget, and Vygotsky (Cakir, 2008), manusia merupakan active meaning makers (pembuat makna yang aktif) pada saat berinteraksi dengan lingkungan sekitar (Hildebrandt \& Zan, 
2008). Melalui keterlibatan aktif, pembaca melakukan asimilasi informasi, mengakomodasi ide baru, dan membangun kerangka konseptual dan skema-skema. Skema merupakan struktur pengetahuan secara keseluruhan yang bersarang di long-term memory (memori jangka panjang). Skema dapat membantu pemahaman dan dapat bertahan di memori jangka panjang sehingga pembaca akan bisa menceritakan kembali dengan lebih baik (Poulsen et al, 1979). Skema dibentuk dari pengalaman-pengalaman yang sama atau yang berulang-ulang. Skema menjadi top-down tool (alat dari otak kita) dalam menginterpretasi peristiwa. Skema akan mengarahkan persepsi kita dan penentuan informasi mana yang akan diperoleh. Skema merupakan struktur dan untuk menjadikannya dilakukan dengan cara logically interrelating different aspects (saling mengaitkan secara logis antar aspek). Jadi pada prinsipnya skema bisa memfasilitasi pemrosesan informasi sehingga pembaca bisa mengkonsktruksi makna.

Sebaliknya, kita sebagai orang dewasa memiliki kemampuan untuk mengakomodasi informasi baru dan juga mengubah pikiran kita. Ketika anda tidak sependapat dengan teman anda tentang tema suatu film, bisakah pikiran anda berubah? Tentunya anda akan bersikukuh dengan pendapat anda sendiri. Jika begitu, berarti kekuatan skema di otak sangat kuat (Smith \& Swinney, 1992). Skema tersebut merupakan struktur pengetahuan yang telah anda miliki. Skema diaktifasi oleh stimulus yang menyentuh elemenelemen dari pola-pola yang ada di memori anda. Skema sangat sulit berubah. Skema yang kuat bisa mengabaikan konflik mental dan konflik emosional yang ada dan perubahan itu tidak begitu dengan mudah terjadi pada anak-anak.

Seorang anak bisa saja mempunyai intuisi tentang pesan yang ada pada bacaan. Tapi bisa saja orang dewasa menyalahkan mereka dan menunjukkan yang benar. Lalu apa yang akan dilakukan anak? Si anak mungkin akan menerima saja. Dia tidak bisa memiliki perspektif sebagai orang dewasa dan berlaku sebagai orang dewasa. Anak-anak masih belum bisa dengan mudah mengakomodasi berbagai sudut pandang yang baru. Mereka hanya bisa mendengarkan. Dia lebih mudah mendapatkan pesan dari nonton film. Pikiran anak masih sulit berubah, sebelum kognitifnya mencukupi untuk bisa mengubahnya sehingga mereka akan dengan mudah menerima isi cerita dari buku yang dibacanya.

Para ahli pendidikan karakter masih belum memperhatikan bagaimana membantu siswa memahami tema moral. Mereka masih mengandalkan pemahaman tema moral dan belum menggarap pedagoginya. Artinya mereka masih mengandalkan teori skema. Mereka masih mengalami kesulitan tentang bagaimana membuat siswa menemukan tema moral. Anak-anak masih mengalami kesulitan mengasimilasi tema moral dari bacaan dengan kemampuan pemahamannya yang didasarkan pada skema yang telah dimilikinya. Tema moral dalam bacaan sangat berpengaruh pada narasi moral yang 
dibangun oleh anak (Narvaez, 1998). Narasi yang dibangun anak bisa berbeda di antara mereka (Narvaez, 2002).

\section{Representasi Mental Sebagai Hasil Pemahaman Teks}

Namun demikian kaum tradisional tidak berpandangan seperti di atas. Menurut pandangan tradisional, tema-tema moral (dan kebajikan-kebajikan moral) diwariskan dari generasi ke generasi. Mereka tidak mendasarkan diri pada perkembangan teori belajar modern. Pandangan tradisional ini lebih menekankan pada peniruan atau membeo, sedangkan yang modern menekankan adanya self-efficacy training (belajar menurut kebutuhan sendiri).

Pengetahuan awal, skema kognitif sangat menentukan dalam mengkonstruksi makna dari bacaan. Apa yang terjadi jika pembaca menghadapi bacaan yang kurang familier? Jika pembaca kurang memiliki pengetahuan awal (tidak memiliki skema yang cukup), pembaca akan sulit memahami, sulit menafsirkan. Hal itu disebabkan oleh tidak adanya skema yang ada di otak pembacanya. Seperti juga orang dewasa, anak-anak juga membangun interpretasinya sendiri dan membangun kesimpulannya sendiri (Graesser et al, 1994), dia membangun representasi mental dari teks (Gambrell \& Jawitz, 1993), dan dari kata-kata yang ada dalam teks (Johnson-Laird, 1987) dengan didasarkan pada pengetahuan awalnya. Anak-anak bisa menemukan temanya (Kurtz \& Schober, 2001). Setiap pembaca memang bisa berbeda kemampuan untuk memahami bacaan yang dibaca (Adam \& Carpenter, 1992), karena pengetahuan awal juga sangat menentukan perbedaan pemahaman pembaca (Shapiro, 2004) dalam membangun tema. Skema tersebut akan membantu pembaca nantinya dalam menuangkan kembali pemahamannya dari teks yang telah dibaca (Zhang, 2008).

Dalam penelitian membaca, ada temuan-temuan penting. Ketika membaca, pembaca melakukan interpretasi aktif terhadap teks. Pembaca merupakan active interpreter (penafsir aktif). Informasi yang masuk akan dipetakan dalam skema (Adams \& Collins, 1977). Ketika menghadapi teks yang kompleks sifatnya, pembaca juga akan melakukan multiple interpretations (tafsiran jamak). Pembaca memiliki gambaran dari isi teks (Zwaan, 1999) dan membangun apa yang disebut dengan representasi mental (Mandik, 2001; Zwaan \& Madden, 2004; Mishraa \& Brewer, 2003) atau mental imagery sebagai suatu gambaran-gambaran di otaknya tentang yang ada di teks (Pressley, 1976). Psikoemosional, latarbelakang budaya dan status sosial bersama-sama dengan apa yang ada dalam internal diri pembaca berpengaruh terhadap pemahaman teks (Doolitle, 2014). Akibatnya interpretasinya bersifat subjektif. Pembaca membangun representasi mental yang benar-benar relevan dengan dirinya sendiri (Johnson-Laird, 1980). Jadi pemahamannya sangat terpengaruh oleh apa yang telah dimilikinya. 


\section{SIMPULAN}

Pengembangan keputusan moral dari membaca telah banyak diteliti pengaruhnya. Beberapa penelitian menunjukkan bahwa perlakuan membaca memberi pengaruh positif pada karakter siswa. Teks moral yang digunakan dalam pendidikan karakter sebaiknya berisi cerita-cerita moral yang sederhana. Cerita-cerita yang pendek sangat bermanfaat dalam pembelajaran karakter di kelas.

Dalam membaca teks, orang yang membaca sebenarnya merupakan active comprehenders (orang yang memahami bacaan secara aktif) dimana skema kognitif sangat membantu dalam mengkonstruksi representasi mental. Skema bisa memfasilitasi pemrosesan informasi sehingga pembaca bisa mengkonsktruksi makna. Mereka juga secara aktif mengkonstruksi makna dari teks dengan menggunakan pengetahuan awalnya. Setiap pembaca memang bisa berbeda kemampuan untuk memahami bacaan yang dibaca, karena pengetahuan awal juga sangat menentukan pemahaman pembaca dalam membangun tema. Pengetahuan awal dan skema kognitif sangat menentukan dalam membangun representasi mental terhadap teks yang dibaca. Oleh karena itu, pembelajaran karakter melalui kisah tidak disangsikan lagi keefektifannya.

\section{RUJUKAN}

Adams, M. J. \& Collins, A. 1977. A schema-theoretic view of reading. Technical Report No. 32. University Of Illinois at Urbana-Champaign: Center for the Study of Reading.

Adam, M. \& Carpenter, P. A. 1992. A capacity theory of comprehension: individual differences in working memory. Psychological Review, 99 (1), 122-149.

Agboola, A. \& Tsai, K. C. 2012. Bring character education into classroom. European Journal of Educational Research, 1 (2), 163-170.

Almerico, G. M. 2014. Building character through literacy with children's literature. Research in Higher Education Journal, 26, 1-13.

Bower, G. H. 1976. Experiments on story understanding and recall. Quarterly Journal of Experimental Psychology, 28:4, 511-534

Caillies, S., Denhiere, G. \& Kintsch, W. 2002. The effect of prior knowledge on understanding from text: Evidence from primed recognition. European Journal of Cognitive Psychology, 14 (2), 267-286. 
Cakir, M. 2008. Constructivist approaches to learning in science and their implications for science pedagogy: a literature review. International Journal of Environmental \& Science Education, 3 (4), 193-206.

Derry, S. J. 1996. Cognitive schema theory in the constructivist debate. Educational Psychologist, 31 (3/4), 163-174.

Doolittle, P. E. 2014. Complex constructivism: a theoretical model of complexity and cognition. International Journal of Teaching and Learning in Higher Education, 26 (3), 485-498.

Driver, S., Asoko, H., Leach,J., \& Mortimer, E. 1994. Constructing scientific knowledge in the classroom. Educational Researcher, 23 (7), 5-12.

Gambrell, L. B. \& Jawitz, P. B. 1993. Mental imagery, text illustrations, and children' story comprehension and recall. Reading Research Quarterly, 28 (3), 264-276.

Graesser,A. C., Singer, M., \& Trabasso, T. 1994. Constructing inferences during narrative text comprehension. Psychological Review, 101 (3), 371-395.

Hildebrandt, C. \& Zan, B. 2008. Constructivist approaches to moral education in early childhood. Dalam Larry P. Nucci \& Darcia Narvaez. Handbook of moral and character education. New York: Routledge. Halaman 352-369.

Jazimah, I. 2016. S.K. Trimurti: Pejuang Perempuan Indonesia. Jakarta: Gramedia.

Johnson-Laird, P. N.1980. Mental models in cognitive science. Cognitive Science, 4, 71115.

Johnson-Laird, P. N. 1987. The mental representation of the meaning of words. Cognition, $25,189-211$.

Kamalski, J., Sanders, T. \& Lentz, L. 2008. Coherence marking, prior knowledge, and comprehension of informative and persuasive texts: sorting things out. Discourse Processes, 45, 323-345.

Kelly, E. M. 2014. The relationship between readers' prior knowledge and comprehension. Tesis. State University of New York at Fredonia

Kurtz, V. \& Schober, M.F. 2001. Readers' varying interpretations of theme in short fiction. Poetics, 29,139-166.

Lee, K., Talwar, V., McCarthy, A., \& Ross, I. 2014. Can classic moral stories promote honesty in children? Psychological Science, 25(8) 1630-1636.

Liu, T. C., Lin, Y. C. \& Paas, F. 2014. Effects of prior knowledge on learning from different compositions of representations in a mobile learning environment. Computers \& Education, 72, 328-338. 
Mandik, P. 2001. Mental representation and the subjectivity of consciousness. Philosophical Psychology, 14 (2), 179-202.

Mishraa, P. \& Brewer, W. F. 2003. Theories as a form of mental representation and their role in the recall of text information. Contemporary Educational Psychology, 28, 277-303

Narvaez, D. 1998. The Influence of Moral Schemas on the Reconstruction of Moral Narratives in Eighth Graders and College Students. Journal of Educational Psychology, 90 (1), 13-24.

Narvaez, D. (2001). Nurturing Character in the middle school classroom: introduction to the project and framework. Minnesota Department of Children, Families and Learning \& Th University of Minnesota.

Narvaez, D. 2002. Does Reading Moral Stories Build Character? Educational Psychology Review, 14 (2), 155-171.

Peraturan Presiden Republik Indonesia Nomer 87 tahunn 2017 tentang Penguatan Pendidikan Karakter.

Poulsen, D., Kintsch, E., Kintsch, W. \& Premack, D. 1979. Children's Comprehension and Memory for Stories. Journal Of Experimental Child Psychology, 28, 379-403.

Pressley, G. M. 1976. Mental imagery helps eight-year-olds remember what they read. Journal of Educational Psychology, 68 (3), 356-358.

Prestwich, D. L. 2004. Character education in America's schools. The School Community Journal, 14 (1): 139-150.

Recht, D. R. \& Leslie, L.1998. Effect of prior knowledge on good and poor readers' memory of text. Journal of Educational Psychology, 80 (1), 16-20.

Sanchez, T., Zam, G., \& Lambert, J. 2009. Story-telling as an effective strategy in teaching character education in Middle Grade Social Studies. Journal for The Liberal Arts and Sciences, 13 (2): 14-23.

Shapiro, A. M. 2004. How including prior knowledge as a subject variable may change outcomes of learning research. American Educational Research Journal, 41 (1), 159-189.

Smith, E. E. \& Swinney, D. A. 1992. The role of schemas in reading text: a real-time examination. Discourse Processes, 15, 303-316.

Stein, N. L. \& Trabasso , T. 1981. What's in a story:an approach to comprehension and instruction. Technical Report No. 200. University Of Illinois at Urbana-Champaign: Center for the Study of Reading.

Subur. 2015. Pembelajaran nilai morral berbasis kisah cetakan 1. Yogyakarta: Kalimedia. 
Terwel, J. 1999. Constructivism and its implications for curriculum theory and practice. Journal of Curriculum Studies, 31 (2), 195-199.

Tyra, C. Bringing books to life: teaching character education through children's literature. Diakses pada tanggal 9 April 2018 dari tccl.rit.albany.edu/knilt/images/f/fe/Tyra.pdf

Vitz, P. C. 1990. The use of stories in moral development: new psychological reasons for an old education method. American psychologist, 45(6): 709-720.

Walker, C. M. \& Lombrozo, T. 2017. Explaining the moral of the story. Cognition, 167, 266-281.

Zhang, C. 2010. The teaching of reading comprehension under the psychology schemata theory. Journal of Language Teaching and Research, 1 (4), 457-459.

Zhang, X. 2008. The effects of formal schema on reading comprehension-an experiment with Chinese EFL readers. Computational Linguistics and Chinese Language Processing, 13 (2), 197-214.

Zwaan, R. A. 1999. Situation models: the mental leap into imagined worlds. Current Directions In Psychological Science, 8 (1), 15-18.

Zwaan, R. A. \& Madden, C. J. 2004. Updating situation models. Journal of Experimental Psychology, 30 (1), 283-288. 